\title{
REPRESENTAÇÕES DA TORTURA: O FAZER LITERÁRIO COMO ESPAÇO DE REMISSÃO
}

\author{
REPRESENTATIONS OF TORTURE: LITERARY SPACE \\ AND REMISSION
}

Cleber José de Oliveira'

\begin{abstract}
RESUMO: Os romances Em câmara lenta (1977), de Renato Tapajós, Batismo de Sangue (1982), de Frei Betto, Volto semana que vem (2015), de Maria Pila, e Ainda estou aqui (2015), de Marcelo Rubens Paiva, sáo compreendidos aqui, sobretudo, como representaçōes denunciativas do modus operandi e das práticas de tortura promovidas por agentes da Ditadura Militar instaurada no Brasil (1964-1985). Nesse sentido, discuto aqui a hipótese central, a saber: ao escreverem sobre memórias tăo dolorosas, os referidos autores configuraram o fazer literário num espaço de remissấo, mas náo de esquecimento, para si e para seus leitores. Já que, sem exceçâo, suas narrativas apresentam um caráter verossímil que entrelaçam suas vidas aos contextos de repressăo e violência física e psicológica, aos quais foram submetidos. Para tanto, traçou-se um panorama analítico-comparativo entre os relatos colhidos pela Comissăo Nacional da Verdade, e publicados em seu relatório final em 2015, e trechos dos referidos romances cujo foco se dá na descriçâo dos atos de tortura de suas personagens. Os resultados apontaram que as tais obras se configuraram como espaços de dor, de denúncia, de resistência e, sobretudo, de remissăo, para seus autores e leitores.
\end{abstract}

Palavras-chave: literatura brasileira; ditatura; tortura; resistência.

ABSTRACT: The novels Em câmara lenta (1977), by Renato Tapajós, Batismo de Sangue (1982), by Frei Betto, Volto semana que vem (2015), by Maria Pila, e Ainda estou aqui (2015), by Marcelo Rubens Paiva are understood here above all as denunciative denunciation representations of the modus operandi and the torture practices promoted by agents of the Military Dictatorship established in Brazil (1964-1985). In this sense, here I discuss the central hypothesis, namely: in writing about such painful memories, these authors configured literary writing as a space of remission, but not as forgetfulness, for themselves and their readers. Since, without exception, their narratives have a credible character that intertwine their lives with the contexts of repression and physical and psychological violence to which they were subjected. For this, an analytical-comparative panorama was drawn between the reports collected by

$\overline{1}$ Doutorando em Letras pela Universidade nacional de Brasília (UnB). Professor nos cursos de Letras e de Pedagogia da Universidade Estadual de Mato Grosso do Sul (UEMS). E-mail: cleber101578@gmail.com 
the National Commission of Truth, published in its final report in 2015, and excerpts of the referred novels whose focus is on the description of the acts of torture of their characters. The results indicated that these works were configured as pain, denunciation, resistance and, above all, remission spaces, for their authors and readers.

Keywords: brazilian literature; dictatorship; torture; resistance.

Previsāo do tempo:

Tempo negro.

Temperatura sufocante.

$O$ ar está irrespirável.

O país está sendo varrido por fortes ventos. Máx.: 38 em Brasília.Mín.:5, nas Laranjeiras. (Jornal do Brasil, no dia seguinte à decretaçâo do AI-5)

O que se lê a seguir săo reflexóes desenvolvidas sobre romances brasileiros contemporâneos, mais especificamente dos trechos que retratam os atos de tortura promovidos pelo regime militar brasileiro. Isso, para entrever em que medida essas narrativas podem atuar como espaços de humanizaçăo (Candido, 1972; 2004) e consequentemente de remissáo, seja para seus autores (que nâo raro foram vítimas de tortura) seja para leitores.

Para tanto, considera que o período entre 1964 a 1985 (instauraçăo e ocaso da ditadura militar), como se sabe, foi marcado, sobretudo, pela desestabilizaçáo da democracia nacional e cerceamento das liberdades de expressáo. Sua face mais cruel se dá a partir da instauraçăo do AI-5 em 1968 até 1973, reconhecidamente o momento mais violento do golpe (VIEIRA, 2014).

Partindo desses pressupostos, traça-se um panorama comparativo sob a perspectiva de compreender como cada autor (dos romances selecionados), com sua sensibilidade e habilidade literária, tratou em seu texto, a barbárie da tortura sofrida - ora por eles próprios, ora por parentes e/ou amigos - durante o regime. Nesse sentido, a perspectiva de recorte analítico deste artigo se dá sobre os trechos em que săo narradas as cenas de tortura. Isso para sustentar a hipótese de que os autores, dos romances já citados, configuram sua narrativa como um espaço de remissâo e acolhimento, para si próprios e para os que foram e sâo atingidos direta ou indiretamente pelos atos de tortura da ditadura militar e por que náo para os que a promoveram.

As obras que serăo analisadas săo: Em câmara lenta (1977), de Renato Tapajós; Batismo de Sangue (1982), de Frei Betto; Volto semana que vem (2015), de Maria Pila; e Ainda estou aqui (2015), de Marcelo Rubens Paiva, respectivamente nesta ordem. As discussóes estăo dispostas da seguinte maneira: um tópico inicial com algumas consideraçōes teóricas sobre o conceito de tortura, seguido de uma discussāo sobre representaçăo literária da tortura e, por fim, as análises comparativas dos trechos escolhidos. 


\title{
SOBRE A TORTURA
}

É fato notório que a tortura foi o método de coerçâo mais utilizado pelo regime militar brasileiro. Essa repressăo, na forma de tortura, năo teve nada de improvisado, năo foram excessos de um ou outro militar mais violento. Foi algo planejado e estruturado realizado sob o comando das Forças Armadas, que empregaram seus homens, instalaçôes e conhecimentos para esse fim (VIEIRA, 2014).

No livro Brasil: nunca mais (1996), Hélio Pellegrino expóe que:

\begin{abstract}
a tortura busca, à custa do sofrimento corporal insustentável, introduzir uma cunha que leve à cisáo entre o corpo e a mente. E, mais do que isto: ela procura, a todo preço, semear a discórdia e a guerra entre o corpo e a mente. 0 projeto da tortura implica numa negaçấo total - e totalitária - da pessoa, enquanto ser encarnado. [...] o discurso que ela busca, através da intimidaçáo e da violência, é a palavra aviltada de um sujeito que, nas mấos do torturador, se transforma em objeto (PELLEGRINO, 1996, p. 282)
\end{abstract}

Pellegrino expóe quais sáo as etapas do projeto de torturar. Explicita que centralmente está a ideia de - desumanizaçăo do ser. Seguido da desconfiguraçấo da identidade social e familiar dos torturados. Com isso, o ser se torna objeto. Náo raro, muitos torturados tiveram a vida levada a cabo ainda na primeira etapa, como descortinou o Relatório Final da Comissâo Nacional da Verdade (2014).

Nesta mesma linha de reflexăo, Viñar e Viñar, em Exílio e Tortura, apontam também que o objetivo da tortura pode ser definido como "provocar a explosâo das estruturas arcaicas constitutivas do sujeito, isto é, destruir a articulaçăo primária entre o corpo e a linguagem" (1992, p. 73). Os autores mapearam, ao longo de suas pesquisas, três etapas que ocorrem numa seçăo de tortura, a saber: $1^{\circ}$ - a destruiçăo dos valores e convicçôes do indivíduo; $2^{\circ}$ - a desorganizaçâo da relaçăo do sujeito consigo mesmo e com o mundo; $3^{\circ}$ - a resoluçấo desta experiência-limite na degradaçăo da memória.

As teses de Pellegrino, Viñar e Viñar, săo confirmadas em diversos relatos, de sobreviventes da tortura, aqui retomo alguns como os de Maria Amélia Teles (ex-militante do Partido Comunista do Brasil- PCB): - Me amarraram na cadeira do dragâo, nua, e me deram choque no ânus, na vagina, no umbigo, no seio, na boca, no ouvido; os de Gilse Cosenza (Ex-militante da Açăo Popular-AP): - Eles usavam e abusavam. Só nos interrogavam totalmente nuas, juntando a dor da tortura física à humilhaçáo da tortura sexual; e também os de Maria do Carmo Serra Azul (conhecida pelos ativistas como Cacau): - É como se eles corrompessem sua alma, destruindo o que você tem de bom (....). Eles querem, através do massacre, da desumanidade, que você traía, que você rompa todos os vínculos que tem, como no caso que eu vi, de uma menina que entregou o próprio pai". Como se vê a crueldade foi e ainda é, devido aos traumas e sequelas deixados, incomensurável. Estes, e tantos outros registros, sâo partes integrantes do Relatório Final da Comissāo Nacional da Verdade (2014).

Ainda sobre a barbárie da tortura, Alves (1996) pondera que houve um emprego generalizado da tortura nos presos políticos para que se confirmasse informaçôes sobre identidades de outros possíveis envolvidos com os grupos insurgentes e os locais de suas reuniōes. Tudo a pretexto de acabar com a tal ameaça comunista. No entanto, 
o que realmente interessava era a manutençăo do status quo militar e dos privilégios das elites civis (midiáticas, econômicas) que davam apoio direto aos militares. Nas palavras do autor:

O emprego generalizado de torturas contra presos políticos provou, mais uma vez, que a flagelaçăo de prisioneiros é método pouco eficiente de obter segredos e informaçóes. Pois, em inúmeros casos, aos torturados náo lhes foram sequer feitas perguntas objetivas e concretas. As engrenagens da dor chegaram a um tal grau de automatismo que os carcereiros colocavam os inquiridos automaticamente na máquina de destruiçấo e quando lhes ofereciam vagar para responder às perguntas seu estado era táo débil que nada podiam dizer. O processo das torturas é também o processo da sociedade brasileira. $O$ pensamento das classes dominantes, prontas a compactuar com atrocidades a fim de preservar a aparente paz em que vive e, sobretudo, os imensos privilégios e poder de que dispóe (ALVES, 1996, p.19-21)

Como se vê no trecho o autor explicita o caráter de ódio político nos atos de tortura. Aponta ainda a ineficácia desses atos em relaçăo ao objetivo de obter informaçōes a respeito de outros grupos de resistência, no entanto sabe-se que os próprios insurgentes, em geral, náo se conheciam e as informaçóes sobre açôes a serem realizadas chegavam horas antes - estratégia utilizada para autoproteçâo - e isso acabava por atiçar a sanha dos torturadores. Nâo é demais ressaltar que a tortura foi o método de coerçăo mais utilizado pelo Estado brasileiro contra seus adversários políticos e também contra a parte da sociedade que năo figurava como protagonista nos planos do status quo.

Destarte, Alves nos faz olhar e refletir sobre o cenário sociopolítico atual. O que se vê neste cenário é preocupante, pois a todo o momento, em atos públicos, săo manifestadas atitudes de louvor à barbárie, de defesa do ódio, de eliminaçâo do outro. Nâo raro se vê discursos odiosos proferidos por representantes do estado e também por representantes das classes sociais mais abastadas. O perigo destes posicionamentos para o corpo social é que se admita, como normal, que açōes de representantes do Estado (agentes da segurança pública) pagos pelos contribuintes sejam mais violentas e cruéis do que a daqueles que julgamos que deveriam estar presos justamente por serem violentos.

Nesse sentido, entendo que os romances selecionados podem ser entrevistos também como possibilidades de combate ao crescente louvor à tortura e a barbárie, que ideologicamente sâo (e foram) inseridos na tessitura das relaçóes sociais brasileiras. Considerando todas essas ponderaçôes, cabe o questionamento: como a literatura pode atuar como um espaço de amenizaçâo da dor causada por traumas relacionados à tortura sofrida e a possibilidade de configurar-se como espaço de reconciliaçăo psicológica. É isso que exponho a seguir.

\section{LITERATURA E REPRESENTAÇÃO DA TORTURA}

De fato, é possível entrever na literatura algumas funçăo(ōes), dentre outras centenas, tais como: representaçăo e denúncia do real, a possibilidade de humanizaçâo, o ato da escrita literária com libertaçáo e remissăo. Sobre isso, Auerbach (1971) direciona nosso olhar para a mímeses, ou seja, a imitaçáo por meio da representaçâo 
dessa realidade passa a buscar o essencial das coisas mediante uma narrativa que tenta apanhar um instante qualquer da vida de uma personagem ou instantes distintos de diferentes personagens para ora coloca-la(s) em confronto com seus "fantasma"; ora para libertá-las de seus traumas individuais e coletivos. Por certo que isso ultrapassa a linha do ficcional e acaba sendo também uma possibilidade para o próprio autor e năo raro para o leitor se redimir e romper traumas reais.

Nessa busca, certamente o registro literário pode ser entendido como uma técnica mimética de percepçâo do humano, dos fatos sociopolíticos e culturais que ocorrem na vida cotidiana, as quais transcendem o simples relato e/ou descriçăo dos mesmos. Para tanto, a sensibilidade na escrita literária contemporânea, alcançada por alguns de seus escritores, muito tem contribuído para um olhar panorâmico, mas năo raso, das mazelas promovidas pelo Estado brasileiro. Nesse sentido, entendo que a literatura contemporânea, pelo menos em parte, tem nos proporcionado enfoques interessantes sobre as relaçóes de poder na esfera sociopolítica e as tensōes e conflitos que surgem daí e que promoveram rupturas que marcam negativamente história recente do país. A instauraçáo legalizada dos meios de tortura, pelo Estado, é, certamente, exemplo dessas rupturas sócio-institucionais que desestabilizaram o estado democrático de direito.

Ainda sobre a literatura e suas possíveis formas de intervençôes na esfera social, pode-se dizer que o fazer literário nos faz olharmos de outra perspectiva as belezas e também as mazelas que ocorrem na vida social, pois está consubstanciada em fatos ocorridos na vida real, ou seja, o fio de Ariadne que liga ficçăo e realidade é a verossimilhança.

Sobre isso, Candido (2004) aponta que a literatura confirma no homem a sua humanidade. Segundo o autor essa seria a principal funçăo da literatura na sociedade. 0 possível processo de humanizaçâo pela literatura, pelo fazer literário, é compreendido pelo autor como sendo:

\footnotetext{
o processo que confirma no homem aqueles traços que reputamos essenciais, como o exercício da reflexăo, a aquisiçấo do saber, a boa disposiçấo para com o próximo, o afinamento das emoçóes, a capacidade de penetrar nos problemas da vida, o senso da beleza, a percepçáo da complexidade do mundo e dos seres, o cultivo do humor. A literatura desenvolve em nós a quota de humanidade na medida em que nos torna mais compreensivos e abertos à natureza, à sociedade e ao semelhante (CANDIDO, 2004, p.180)
}

Essa ponderaçăo me ajuda, e muito, na sustentaçăo de uma das hipóteses propostas neste artigo, a saber: a literatura como sendo um espaço de remissáo para autores e leitores que de algum modo foram atingidos fisicamente e psicologicamente pela tortura. Isso no sentido de que sem humanizaçăo năo pode haver remissăo. Por remissâo entenda-se: o processo de conciliaçăo entre personagem e suas angústias, corpo e memória, autor e seus traumas, o sentimento de perdáo se sobrepondo ao ódio e a vingança.

Nesse sentido, a discussăo agora caminhará sob a perspectiva de entrever em que medida a literatura, por meio da característica de verossimilhança, aproxima o real e o ficcional em relaçấo aos momentos de tortura pelo qual passaram algumas personagens dos romances já citados. Outra questâo é como ela (a literatura) pode se configurar 
como espaço de humanizaçăo (nos moldes traçados por Candido), de remissăo e de registro denunciativos dos momentos - sejam eles de natureza física, sentimental ou psicológica - que marcam profundamente a existência do ser humano que esteve envolto à tortura praticada pelo regime militar.

Isto ponderado, vejamos agora como autores, personagens e obras se inter-relacionam no interior do espaço de representaçăo literário.

\section{EM CÂMARA LENTA}

Dos romances selecionados, Em câmara lenta, de Renato Tapajós é, sem dúvida, o que mais expóe os atos de tortura em suas minúcias. $O$ trecho a seguir é uma das cenas mais emblemáticas da obra, isso dentro da perspectiva do recorte analítico proposto neste artigo. Na cena, săo narrados os atos de tortura que culminam na morte, por esmagamento de crânio devido ao uso do instrumento de tortura coroa-de-cristo, da personagem "ela". Quem narra é a personagem "ele" (companheiro amoroso e de resistência ao regime de "ela")

Cercaram-na e caíram sobre ela, acertando socos em seu rosto, pontapés em suas costas, tentando segurá-la. Ela se debateu com violência, mas uma forte coronhada em sua nuca a fez tontear. Um policial segurou-a firmemente, enquanto outro fechava as algemas em seus pulsos delicados. Puxaram-na pelas algemas: ela caiu ao chăo e foi arrastada, rasgando a roupa e a pele macia de encontro às pedras do terreno [...] Ela tentava se defender, atingindo um ou outro agressor, mas eles a lançaram no cháo, já nua e com o corpo coberto de marcas e respingos de sangue. 0 canto de seus lábios estava rasgado e o ferimento ia até o queixo. Eles a seguravam no chăo pelos braços e pernas, um deles pisava em seu estômago e outro em seu pescoço sufocando-a. O que a pisava no estômago perguntou-lhe novamente o nome. O outro retirou o pé do pescoço para que ela pudesse responder, mas ela nada falou. Nem gemeu. Apenas seus olhos brilharam de ódio e desafio. O policial apertou-lhe o estômago com o pé, enquanto outro chutou-lhe a cabeça, atingindo-a na têmpora. Sua cabeça balançou, mas quando ela voltou a olhar para cima, seu olhar náo havia mudado. O policial enfurecido sacou o revólver e apontou para ela, ameaçando atirar se continuasse calada. Ela continuou e ele atirou em seu braço. Ela estremeceu quando a bala rompeu o osso pouco abaixo do cotovelo [...] procurava contrair o braço sadio, para evitar que o peso repousasse sobre o outro, enquanto eles amarravam os terminais de vários magnetos em suas mâos, pés, seios, vagina e no ferimento do braço. Os choques incessantes faziam seu corpo tremer e se contrair, atravessavamna como milhares de punhais e a dor era tanta que ela só tinha uma consciência muito tênue do que acontecia. Furiosos, os policiais tiraram-na do pau-de-arara, jogaram-na ao cháo. Um deles enfiou na cabeça dela a coroa-de-cristo: um anel de metal com parafusos que o faziam diminuir de diâmetro. Eles esperaram que ela voltasse a si e disseram-lhe que se năo começasse a falar, iria morrer lentamente. [...] Ele continuou a apertar os parafusos e um dos olhos dela saltou para fora da órbita devido à pressáo no crânio. Quando os ossos do crânio estalaram e afundaram, ela já havia perdido a consciência, deslizando para a morte com o cérebro esmagado lentamente (TAPAJÓS, 1977, p. 169-172).

A representaçâo da tortura, neste trecho, se dá de forma nua e crua, contudo a narraçấo nâo se configura na esfera do mero relato panfletário, pois o transcende. Ao transcender o simples relato, por meio de sua expertise e sensibilidade literária, 
o autor parece buscar provocar no leitor uma - catarse - que permite conhecer uma situaçâo-limite que pode gerar tanto o temor quanto à piedade. A verossimilhança é outra característica literária forte da narrativa, sobretudo, quando colocada em paralelo aos relatos colhidos pela Comissáo Nacional da Verdade, săo impressionantes o detalhamento e a proximidade com o real. Impossível năo notar os detalhes que se manifestam por meio do movimento narrativo de aproximaçăo metonímica tais como: “O canto de seus lábios estava rasgado e o ferimento ia até o queixo e em: mas quando ela voltou a olhar para cima, seu olhar nâo havia mudado; e de afastamento hiperbólico como $O$ policial enfurecido sacou o revólver e apontou para ela, ameaçando atirar e em Furiosos, os policiais tiraram-na do pau-de-arara, jogaram-na ao châo."

Esse movimento configura uma espécie de vai e vem do foco narrativo, como se fosse um zoom que ora se aproxima e capta, por exemplo, o olhar da vítima e ora se distância para que, de forma ampla, se veja a vítima por inteiro e quăo desumanos sâo as açóes dos torturadores. Isso marca a tessitura literária do trecho no que diz respeito à sua capacidade de representaçâo da dor do outro. Certamente o verossímil talvez seja a característica que mais marca a narrativa.

O registro náo se manifesta em primeira pessoa, todo o trecho é apresentado ao leitor a partir da perspectiva da personagem "ele. Ou seja, as cenas do suplício sofrido por "ela" sấo, na verdade, o que "ele" acredita ter acontecido. Essa construçăo psíquica do como aconteceu ou teria acontecido, de como os policiais a espancaram, a interrogaram e a mataram faz com que o narrador construa seis réplicas desta cena. Cada uma é reproduzida, sob o vai e vem do pensamento-imaginaçâo do narrador, com mais detalhes de como teria sido o martírio sofrido por "ela". Em cada uma das cenas săo adicionados mais e mais detalhes fazendo com que a narrativa passe, ao leitor, a impressăo de estar ocorrendo em slow motion, isto é, em câmara lenta. Isso pode ser tomado como uma característica do fazer literário que se sobrepóe ao simples relato e à mera descriçấo, pois a "força de Em câmara lenta provém do teor estético da linguagem usada e de uma técnica ficcional avançada", como atestou Antonio Candido (1981).

Este atestado de ficcionalidade emitido por Candido foi peça crucial na defesa de Tapajós para que năo fosse novamente preso pelos militares. Registre-se que Em câmara lenta foi escrita clandestinamente ainda quando o autor se encontrava preso e sendo torturado. Pouco depois de sair da prisâo a publicou e isso gerou muito tumulto à época. Tapajós usou a literatura como recurso denunciativo do suplício a qual foi submetido, por outro lado, utilizou-a também como meio de remissăo para combater sentimentos de ódio e vingança que, por certo, lhe invadiram o coraçăo. Nesse sentido, portanto, estaria a literatura lhe servindo como instrumento próprio de humanizaçăo.

\section{BATISMO DE SANGUE}

A ditadura militar no Brasil e seus desdobramentos também é o tema de Batismo de sangue. Contudo, esse romance oferece tal tema ao leitor sob a perspectiva dos freis dominicanos que apoiaram os insurgentes ao regime. Uma perspectiva diferente e interessante. Nesse sentido, a narrativa constitui-se como um registro do engajamento de parte dos religiosos dominicanos contra o regime autoritário militar, pelos direitos humanos e no limite para manterem-se vivos. 
Nessa obra é narrado o ativismo político, a prisăo, as diversas sessóes de tortura, o exílio, até o suicídio de Frei Tito (devido às profundas sequelas psicológicas deixadas pela tortura), e também toda articulaçăo, perseguiçâo e assassinato do líder ativista Carlos Marighela. Dos trechos, encontrados no livro, em que săo registrados e explicitados os atos tortura, certamente, às empregadas em Tito săo as que dâo, ao leitor, a dimensấo da crueldade e sadismo dos torturadores, como é possível constatar no trecho:

Dois fios foram amarrados em minhas măos e um na orelha esquerda. A cada descarga eu estremecia todo, como se o organismo fosse se decompor. Da sessáo de choques passaram-me ao pau-de-arara. Uma hora depois, com o corpo todo ferido e sangrando, desmaiei. Fui desamarrado e reanimado. Conduziram-me a outra sala dizendo que passariam a descarga de 220 volts a fim de que eu falasse antes de morrer [...] (BETTO, 1982, p.263).

\section{O registro literário continua:}

Diante de minhas negativas aplicavam-me choques, davam-me socos, pontapés e pauladas nas costas. Revestidos de aparatos litúrgicos, os policiais me fizeram abrir a boca 'para receber a hóstia sagrada'. Introduziram um fio elétrico. Fiquei com a boca inchada sem poder falar direito (BETTO, 1982, p.264).

Nesse trecho, Frei Tito narra os primeiros momentos nas máos dos torturadores. Note-se que estamos diante da perspectiva do torturado que narra sua própria dor. Já de início esse é um ponto de descontinuidade em relaçâo ao foco narrativo do trecho de tortura citado acima de Em câmara lenta.

A violência que é empregada é descomunal. Até o momento de sua prisăo e tortura Tito gozava da prerrogativa de cidadăo portador de uma vida passível de luto (BUTLER, 2015), ou seja, socialmente seu status de cidadáo que tem o Estado como responsável pela sua segurança lhe era assegurado constitucionalmente. Condiçăo essa abolida pelo AI-5. Na máo dos militares e em meio à tortura essa condiçâo de ser reconhecido como uma pessoa humana digna de luto é revogada. Na cena pode ser visto em açâo o esquema teorizado por Viñar e Viñar (1992) e por Pellegrino (1996). Nesse sentido, o estatuto de cidadăo livre e com prerrogativa de inocência é usurpado, devido a sua prisăo arbitraria. E em meio a tortura sua condiçăo humana negada.

Além disso, um depoimento de Frei Tito, redigido por ele mesmo na prisăo, em fevereiro de 1970, é retomado e incorporado por Frei Betto em Batismo de Sangue. Este depoimento foi retirado clandestinamente da prisăo (assim como os manuscritos de Em câmara lenta) e logo após publicado pelas revistas Look e Europeo, no mesmo ano, o qual dizia:

no dia 17 de fevereiro de 1970, $3^{a}$ feira, às 14 horas. O capităo Maurício veio buscarme em companhia de dois policiais e disse: "Você agora vai conhecer a sucursal do inferno". Algemaram minhas mâos, jogaram me no porta-malas da perua. No caminho as torturas tiveram início: cutiladas na cabeça e no pescoço, apontavamme seus revólveres. 
Preso desde novembro de 1969, eu já havia sido torturado no DOPS. Em dezembro, tive minha prisăo preventiva decretada pela $2^{\mathrm{a}}$ auditoria de guerra da $2^{\mathrm{a}}$ regiáo militar. Fiquei sob responsabilidade do juiz auditor dr Nelson Guimarăes. Soube posteriormente que este juiz autorizara minha ida para a OB sob "garantias de integridade física".

Ao chegar à $\mathrm{OB}$ fui conduzido à sala de interrogatórios. A equipe do capităo Maurício passou a acarear-me com duas pessoas. O assunto era o Congresso da UNE em Ibiúna, em outubro de 1968. Queriam que eu esclarecesse fatos ocorridos naquela época. Apesar de declarar nada saber, insistiam para que eu "confessasse". Pouco depois levaram me para o "pau-de-arara". Dependurado nu, com máos e pés amarrados, recebi choques elétricos, de pilha seca, nos tendōes dos pés e na cabeça. Eram seis os torturadores, comandados pelo capitâo Maurício. Davam-me "telefones" (tapas nos ouvidos) e berravam impropérios. Isto durou cerca de uma hora. Descansei quinze minutos ao ser retirado do "pau-de-arara". O interrogatório reiniciou. As mesmas perguntas, sob cutiladas e ameaças. Quanto mais eu negava mais fortes as pancadas. A tortura, alternada de perguntas, prosseguiu até às 20 horas. Ao sair da sala, tinha o corpo marcado de hematomas, o rosto inchado, a cabeça pesada e dolorida. Um soldado, carregou-me até a cela 3, onde fiquei sozinho. Era uma cela de 3 X $2,5 \mathrm{~m}$, cheia de pulgas e baratas. Terrível mau cheiro, sem colchăo e cobertor. Dormi de barriga vazia sobre o cimento frio e sujo[...] faço esta denúncia e este apelo a fim de que se evite amanháa triste notícia de mais um morto pelas torturas. (BETTO, 1982, p. 199 [TITO, Brasil, 1970])

O relato-denúncia de Frei Tito fala por si só. A busca pelo verossímil fatídico é marcante. O impacto dessa publicaçáo ecoou pelo mundo, gerando apoio incondicional aos torturados e aos exilados por parte de ativistas e entidades ligadas aos direitos humanos. Por certo, esse é um registro que mostrou ao mundo toda a barbárie que estava acontecendo no Brasil.

Além disso, Frei Tito escreveu uma vasta gama de poemas que, de modo geral, tratam de temas como o perdăo, a devoçâo, as memórias da tortura, a busca pela salvaçâo, entre outros. Talvez os escreveu como forma de libertaçăo dos traumas e angústias psicológicas que se mantiveram vivas e latentes em sua memória. Mesmo vivendo num lugar relativamente seguro (Éveux/França), em relaçâo ao regime militar brasileiro; suicida-se (por enforcamento) em 1974, aos 28 anos.

Sobre o ficcional nos ajudar a suportar a realidade Ferreira Gullar em entrevista ponderou que a literatura existe porque a vida náo basta, porque o real é muito duro e limitado (2012). Nesse sentido, talvez seja possível dizer que Frei Tito tenha resistido, por tanto tempo às açôes de suplício real as quais foi submetido, devido, entre outras, à possibilidade literária de escrever poemas durante o cárcere e fora dele.

Desse modo, é possível entrever que Batismo de Sangue se configura năo só como um discurso literário que se propóe a denunciar a barbárie promovida pelo regime militar, sobretudo, como espaço de busca pela essência humana por meio da capacidade de perdâo e compaixâo ao outro. Por isso, configura-se também como espaço de remissăo aos sentimentos de ira, asco e de vingança para Frei Tito (que na narrativa é incorporado como personagem protagonista juntamente com Carlos Marighela: político, escritor brasileiro e, a partir de 1964, um dos principais organizadores da luta contra a ditadura militar. Chegou a ser considerado o inimigo "número um" da ditadura militar brasileira) como para o autor Frei Betto (que também esteve preso e foi torturado pelo regime). 


\title{
VOLTO SEMANA QUE VEM
}

Volto semana que vem (2015), é uma obra de ficçâo autobiográfica na qual a autora, Maria Pila, narrada sua militância política sua prisáo e seu exílio em paralelo a história de dois outros militantes. As passagens ocorrem nas cidades de Buenos Aires, Paris, Săo Paulo, Porto Alegre. A citaçăo a seguir é o capítulo completo intitulado "2003 / A gatinha do edredom":

\begin{abstract}
Enfiaram um capuz na minha cabeça e me levaram. Dios mio, que engano, pensei para disfarçar o terror. Estava com medo de que a identidade falsa fosse descoberta? Nâo, nada disso. $O$ capuz. Ele anunciava alguma coisa terrível, que eu náo conseguia nem imaginar, mas que tornava irrisório todo o resto, a identidade falsa, o endereço de araque, o sotaque. De repente sentia meu corpo caindo, caindo. Ao redor, as vozes eram muitas. Mais tarde, o silêncio. O telefone - trim trim trim! - năo parava de tocar, e ninguém atendia. Tive uma louca esperança: e se eu avisasse alguém do meu desaparecimento? Quem sabe fosse socorrida. Aterrorizada pelo silêncio e pelo capuz, năo me mexi, continuei quieta no meu canto. Trim trim trim!, insistia o telefone. Virei-me debaixo do edredom e lá estavam os olhos arregalados da gatinha - como sempre fazia -, esperando minha reaçăo. Engano, número errado, respondeu a voz. Quis abraçar o corpo quente e macio do animalzinho. Era só um pesadelo, repetia, contente da vida. Senti uma fisgada aguda no pé e levantei o edredom, agora muito sujo e com cheiro de urina. Debaixo dele, em vez da gatinha, vi meus pés manchados de sangue e estrangulados pela corda. 0 cheiro: inesquecível cheiro de roupa suja misturado a um vago odor de pele queimada pelos fios desencapados (PILLA, 2015, p.45)
\end{abstract}

A narrativa é construída em primeira pessoa. Configura-se numa espécie de pesadelo que acomete a personagem trazendo à tona as angústias e sofrimento dos momentos de martírio. No limite do consciente e do inconsciente no vai e vem de sua memória a personagem faz com que a imagem narrada ganhe singularidade ao compararmos às outras já analisadas aqui. O trecho é metonímico, ou seja, a cena toda construída a partir da parte pelo todo, procedimento metonímico em que a narradora parece convidar o leitor a constituir, a partir do sugerido, a imagem do martírio. Os detalhes da tessitura narrativa criam um efeito sinestésico, podendo levar o leitor a sentir a um vago odor de pele queimada pelos fios desencapados.

O leitor é um dos componentes centrais dessa narrativa. Esse procedimento pode ser entendido como uma característica da literatura contemporânea, pois "nunca fomos tăo invocados pela literatura. É à nossa consciência que se dirigem esses narradores hesitantes, essas personagens perdidas, aguardando nossa adesâo emocional ou ao menos estética", como assevera Dalcastagné (1996, p. 30).

Em novembro de 2015, Maria Pila concedeu uma entrevista ao jornal Sul 21. Dessa entrevista, três questôes me chamam a atençâo na medida em que săo extremamente relevantes para compor uma compreensáo mais aprofundada e densa do entrelaçamento entre a literatura e o contexto de repressăo e tortura que está sendo aqui discutido. Eis as três questôes seguidas de suas respectivas respostas: 


\section{Sul21- Como vês o teu livro como criaçăo literária?}

MP - Alguma coisa eu criei, năo tinha o foco na história. Quero continuar escrevendo. Gosto de escrever, de ler, de conversar sobre essa coisa da criaçăo.

Sul21 - Como era a tortura nas delegacias?

MP - Em geral todas as possibilidades, do estupro ao submarino, aos espancamentos, aos choques elétricos. Onde eu estava era mais a picana (máquina de choques).

Sul21 - O que resta da tortura? Raiva, revolta?

MP - Eu sei bem o que resta. Foi chocante ver pessoas com um comportamento bárbaro, aos gritos. Nâo é possível que essas coisas existam. O filme "Cidadâo Boilesen" narra o prazer (que o empresário tinha) com isso, ele trazendo de presente (para a Oban) uma maquininha de tortura. Graças a Deus fiz oito anos de análise para elaborar isso, senáo ficaria com uma raiva muito grande. Consegui elaborar, controlar essa raiva. Tanto que escrevo o livro sem marca de amargura.

A priori o que se vê na entrevista é uma autora que tem na literatura uma possibilidade de acolhimento. A narrativa embora apresente passagem como a do capítulo reproduzido acima, parece sugerir um sossegar das angustias, uma amenizaçăo da dor em relaçâo às memórias traumáticas, (re)vividas pelo autora-personagem, isso na medida em que do tempo vai fazendo seu trabalho.

Apesar de boa parte das memórias que compóem essa narrativa serem momentos de angústia e violência (como se vê no fragmento acima), é possível entrever, sobretudo, que há uma declaraçâo de alegria irredutível e um louvor à vida. Isto considerado, entendo năo ser possível náo atrelar essa alegria pela vida renovada como ao acolhimento possível da esfera ficcional. Ou seja, é possível dizer que literatura esta atuando, sobretudo, como um espaço de humanizaçăo e de remissăo para a autora, pois afirma estar se reencontrando com a paz, ainda que parcial, quando se debruça no seu fazer literário.

\section{AINDA ESTOU AQUI}

O ponto de partida do romance Ainda estou aqui (2015), de Marcelo Rubens Paiva, é o primeiro grande trauma da sua vida ocorrido ainda quando era criança - o desaparecimento do pai, o deputado federal Rubens Paiva, cassado no golpe de 1964.

O sensato seria nos mudarmos para Londres ou Paris. Minha irmá Vera passava férias em Londres. Deveríamos ter ficado dois ou três anos por lá, como fez o Gasparian. Meu pai perdeu o timing. Onipotência e teimosia que minha măe nunca perdoou. Queria lutar quixotescamente numa guerra já perdida. Arriscou a família. Tinha cinco crianças. E tenho certeza de que, destroçado pela tortura, deve ter pensado nisso. Talvez a dor da tortura năo chegasse aos pés da descoberta de que tomou decisôes erradas, arriscou a vida da mulher e dos filhos, crianças ainda. Deve ter sido a sua derradeira tortura [...] agora náo dá para fugir da morte. Eu vou morrer, sinto que vou, espero que me perdoem. O que fiz prova minha vulnerabilidade, falhas do meu caráter, que pôs tudo a perder e causa muito sofrimento. Que pena que estou 
indo embora, que triste que năo posso ficar, năo me deixam ficar, é inevitável que eu vá, eu náo queria, eu náo queria, estou tăo triste. Tenho que morrer agora. Morreu repetindo o seu nome. Meu nome é Rubens Paiva, meu nome é Rubens Paiva, meu nome é Rubens Paiva, meu nome é Rubens Paiva, meu nome é - Rubens Paiva... Dizem que foi torturado ao som de "Jesus Cristo", de Roberto Carlos, música que a minha irmá Eliana se lembra de ter escutado enquanto estava lá. [...] 20 de janeiro de 1971. Meu pai apanhou por dois dias seguidos. Apanhou assim que chegou na 3a Zona Aérea, interrogado pelo próprio brigadeiro Joăo Paulo Burnier. Apanhou no DOICodi, no quartel do I Exército. Meu pai era um homem calmo, bom, engraçado, frágil fisicamente [...] imaginar este sujeito boa-praça, um dos homens mais simpáticos e risonhos que muitos conheceram, aos quarenta e um anos, nu, apanhando até a morte.... É a peste, é a peste. Dizem que ele pedia água a todo momento. No final, banhado em sangue, repetia apenas o nome. Por horas. Rubens Paiva. Rubens Paiva. Ru-bens Pai-va, Ru... Pai. Até morrer. (PAIVA, 2015, p. 69-70)

O trecho se explicita entre a comoçăo e o drama. Embora năo haja na cena a tortura propriamente dita, o sugestivo metonímico nos leva a entender a angustia do narrador. Parece haver dois instantes narrativos simultâneos que oscilam entre: a priori uma espécie de revolta comedida do filho (Marcelo Rubens Paiva - o filho) para com seu pai devido à demasiada teimosia e a idealizaçăo imódica à causa socialista, caracteristicas marcantes da personalidade de Rubens Paiva (o pai). E a posteriori um forte sentimento de compaixâo do filho pelo sofrimento do pai em face à tortura sofrida. De um modo ou de outro os dois instantes săo manifestados pelo narrador como traumas ainda năo superados, na verdade talvez impossíveis de superaçâo.

Como se vê no trecho, a narrativa revela os momentos de tortura que possivelmente Rubens Paiva vivenciou. No momento de seu suplício buscou pronunciar diversas vezes o próprio nome até morrer. Possivelmente como forma de se manter em să consciência e de năo perder a sua identidade pessoal, numa derradeira tentativa de resistir à terceira e última etapa do projeto de tortura - "experiência-limite na degradaçăo da memória" (VINÂR e VINÂR, 1992). O narrador é quem nos fala sobre o que o pai poderia ter pensado, as palavras que poderia ter usado frente ao martírio. Em alguns momentos parece náo se conforma com as escolhas feitas pelo pai. Em outro momento, por outro lado, parece ter desenvolvido a capacidade de suportar, năo sem dor, a violência acometida contra seu pai. Vejamos outro trecho:

A tortura é a ferramenta de um poder instável, autoritário, que precisa da violência limítrofe para se firmar, e uma aliança sádica entre facínoras, estadistas psicopatas, lideranças de regimes que se mantêm pelo terror e seus comandados. Năo é açáo de um grupo isolado. A tortura é patrocinada pelo Estado. A tortura é um regime, um Estado. Năo é o agente fulano, o oficial sicrano, quem perde a mấo. É a instituiçăo e sua rede de comando hierárquica que torturam. A naçăo que patrocina. 0 poder, emanado pelo povo ou năo, suja as măos. Tortura também serve para inspirar ódio dos próprios torturados por eles mesmos, que se sentem culpados por năo resistirem à pressăo e a dor e entregar companheiros, comparsas, a família, inventar até o que năo fizeram. O torturado se sentirá entăo o próprio repressor, o próprio torturador. Na ditadura, torturaram freis, freiras, bispos, padres brasileiros e estrangeiros, velhos, bebês, grávidas, pais com filhos, máes amarradas diante de filhos, por uma causa torpe (PAIVA, 2015, p.70). 
O que se tem aqui é um trecho no qual o narrador versa sobre a tortura e seus objetivos. Neste registro literário o autor explicita no trecho seu juízo de valor sobre a instrumentalizaçăo da tortura pelo estado. Juízo este que se aproxima, em muito, das definiçōes teóricas, obtidas anteriormente. Ressalta-se que Marcelo năo foi preso, nem vítima de tortura direta, no entanto, é afetado profundamente pelo desaparecimento e assassinato de seu pai.

Registre-se que em 1974, em plena ditadura militar é publicado Oposiçāo no Brasil, hoje, de Marcos Freire, primeiro livro de năo-ficçăo editado de forma legal no Brasil (RFCNV, 2014). Neste săo reproduzidos discursos e debates dos parlamentares sobre a questăo da tortura. 0 capítulo 2, intitulado "Em defesa dos direitos humanos", traz denúncias sobre o desaparecimento do ex-deputado Rubens Paiva, reproduzindo depoimento de sua esposa, Eunice Paiva, além de abordar vários outros casos de pessoas presas e desaparecidas e de denúncias de torturas.

Recentemente, investigaçōes promovidas pela Comissăo Nacional da Verdade, elucidaram este caso a partir de depoimentos de alguns dos militares que participaram da açâo de prisâo que culminou na tortura e a morte de Paiva, como se pode ver neste registro: "no segundo dia de tortura, Rubens Paiva năo resistiu e seu corpo foi enterrado e desenterrado antes de ser lançado ao mar" (RFCNV, 2014). É preciso ressaltar que até entăo a família Paiva, assim como tantas outras famílias, foi torturada psicologicamente devido à ausência de informaçóes sobre o paradeiro do corpo de Rubens Paiva (pai), foram torturados também pela omissăo do Estado e pela indiferença da justiça brasileira.

Embora o romance em questăo tenha sido iniciado anos antes, ele foi finalizado somente em 2014, após a publicaçâo do relatório final e conclusivo da Comissâo Nacional da Verdade. $\mathrm{O}$ autor conclui a narrativa com a seguinte frase: "torturado e morto por militares". Isso porque o relatório traz o depoimento de um dos militares que participaram do sequestro de Rubens Paiva, no qual afirma ter presenciado os atos de tortura e o assassinato do entăo deputado federal. 0 teor dessa finalizaçáo parece querer expressar um de misto sentimentos tais como um certo senso de justiça, alivio e remissâo pela literatura.

Em recente entrevista para a Folha de Sáo Paulo, Marcelo Rubens Paiva afirmou que: "A única forma de resolver essa angústia (desaparecimento do pai) era escrever". Com isso, o autor consolida minha hipótese inicial de que a literatura atua com espaço de remissăo; ou seja, ao resolver sua angústia o autor liberta-se do ódio e do rancor sendo capaz de emanar compaixăo (nâo esquecimento) até mesmo aos torturadores que assassinaram de seu pai. Nesse sentido, a violência pela violência própria dos torturados e assassinos é colocada em xeque pela humanizaçăo literária adquirida pelo autor.

\section{DIÁLOGOS VEROSSÍMEIS}

Como vimos anteriormente, romances e autores têm muito em comum, ainda mais quando observados sobre as perspectivas de seus temas e a biografia de seus autores. E săo, sobretudo, literatura, pois transcendem o simples relato da tortura e a mera descriçấo dos espaços e objetos. Fazem isso por meio da técnica, dos signos e da sensibilidade empregadas, por cada autor, de modo singular em cada narrativa, ainda que 
abordando o mesmo tema e o mesmo momento socio-histórico.

Nesse sentido, essas narrativas podem ser entendidas ainda sob o viés de Dalcastagné (1996), em que pondera

\begin{abstract}
Esses romances săo documentos imprescindíveis de um tempo que ainda năo nos foi revelado por inteiro, de uma história que se tem de continuar fazendo, múltipla e indefinidamente. [...] Documentos que se estabelecem náo como analise dos jogos do poder ou descriçáo de torturas, mas como acolhida à dor de suas vítimas, como espaço onde a história dos vencidos continua se fazendo, lugar onde a memória é resguardada para exemplo e vergonha das geraçóes futuras (DALCASTAGNE, 1996, p. 24-5).
\end{abstract}

E ainda

[...]sáo a expressăo de uma grande dor. Dando voz aos vencidos, eles acolhem também suas feridas, seus gemidos, sua derrota. [...] Das suas paginas năo surgem mártires, nem heróis, mas pessoas comuns (DALCASTAGNE, 1996, p. 137).

É possível entrever nos trechos que o texto literário serviu e serve também como espaço de registro das lutas e resistências contra toda e qualquer forma de violência e exclusăo. Para a autora, a literatura, por autores que de algum modo tiveram sua vida atingida direta ou indiretamente pela barbárie do regime, pode ser configurada num espaço onde estes encontraram acolhimento tantas vezes negado ela dura e concreta realidade da vida real. É fato que a literatura serviu e serve como um espaço de aconchego, de acolhimento das dores, angústias, medos, ou seja, das fragilidades humanas como um todo.

Com isso, é capaz de atrair um conjunto de comiseraçôes que busca (re)afirmar no homem a sua cota de humanidade (Candido, 2004). O literário se liga à vida cotidiana real por meio da verossimilhança que é, pois, uma propriedade interna da obra literária, mesmo quando se apresenta um quadro inteiramente descritivo ou avaliativo. A obra literária caracteriza-se, como já se observou, pelo emprego da linguagem verbal, o que a diferencia, por exemplo, da música e da pintura. Essa linguagem expressa o que a fantasia e a imaginaçấo do escritor nos sugere, o que define sua natureza ficcional. Contudo, o imaginário mais fértil sofre a contençăo da verossimilhança, que determina os limites lógicos e aceitáveis de uma criaçấo literária. A verossimilhança apresenta-se como lei interna, já que a coesáo depende do arranjo dos fatos e das palavras que os manifestam. Mas a verossimilhança igualmente estabelece a relaçăo entre o mundo representado em uma obra e o universo do leitor, que reconhece a validade de um texto de um lado por considerá-lo coerente e de outro por firmar o nexo entre o que é ali mostrado e o que ele sabe por experiência própria.

No caso de Renato Tapajós: esteve preso por cinco anos (1969 a 1974) e foi torturado, "Em Câmara Lenta", nasceu em 1973, enquanto estava preso. Para que o livro pudesse ser escrito, seus pais iam visitá-lo e levavam os minúsculos originais escondidos na boca. Quando lançado, em 1977, Tapajós foi novamente preso e o livro censurado. No tocante a Frei Betto: esteve preso por dois anos e quinze dias e foi torturado pelo DOI-CODI. No caso de Maria Pilla: esteve Presa em Buenos Aires em 1975, foi torturada 
e passou mais de dois anos encarcerada. Expulsa do país em 1977, recebeu asilo da França mais uma vez. De volta ao Brasil com a Anistia de 1979, optou por permanecer em Paris até 1992, quando voltou para o Brasil. Já Marcelo Rubens Paiva: teve seu pai Rubens Beyrodt Paiva (Deputado Federal) morto pelo regime militar, e seu corpo até este momento ainda năo foi localizado, cerceando a família do direito ao luto. Por isso, estes autores, ligados entre si pelos atos e efeitos do suplício (mas năo só estăo também pela literatura), buscam resistir a esses traumas por meio da "arma fraca" que notadamente dominam - a literatura. Com isso, a meu ver, configuram o seu fazer literário como um espaço năo só de denúncia da barbárie, mas antes de tudo - de remissăo; ou seja, conseguiram desenvolver, na longa e árdua experiência literária de suas obras, a capacidade de suportar os traumas físicos e psicológicos por meio da remissăo pelo fazer literário.

Do ponto de vista da esfera democrática que é constituída somente na consolidaçâo do Estado Democrático de Direito, em todas as suas instâncias nacionais e internacionais, esse tipo de açăo - a tortura - que feriu de morte vidas humanas é condenável "aos olhos" da Constituiçăo Federal Brasileira e de organismos internacionais como Organizaçăo das Naçôes Unidas (ONU) e Organizaçăo dos Estados Americanos (OEA) e também da Declaraçáo Internacional dos Direitos Humanos. Embora se saiba que tal prática ainda seja muito utilizada pelo braço armado do Estado, ainda que com outros aspectos e equipamentos, atualmente.

O que se viu no conjunto das imagens literárias aqui apresentadas é justamente o que coloca em xeque os direitos constitucionais, as liberdades democráticas, o Estado de Direito pleno no Brasil. Os discursos e práticas de ódio săo formas de violência que estâo arraigadas no proceder das açóes sociopolíticas de grande parte da sociedade brasileira, sobretudo, à parte ligada ao grande capital e ao poder político que querem manter seus privilégios a todo custo.

Por fim, ressalto que para combater essa ideologia do ódio e da violência se faz imprescindível o discurso literário que é capaz de se configurar no espaço de denúncia e principalmente de remissăo. Isso é possível a partir do entendimento de que a natureza da literatura, do texto literário esta na sua - capacidade de confirmar no homem sua humanidade (Candido,1972; 2004). Já que a mesma literatura que é usada para nortear ideologias e pensamentos pode criar atitudes subversivas, no individuo, aos regimes totalitaristas.

\section{CONSIDERAÇÕES FINAIS}

De modo geral, procurei ponderar aqui que a literatura atua como um espaço de remissăo, acolhimento e humanizaçâo em face aos traumas físicos e psicológicos, ao passo que as denuncia à sociedade. Atua ainda como espaço de acolhimento para frutos da violência da tortura, servindo assim para o autor e o leitor como uma espécie de válvula de escape e afago. O que a configura também como lugar de combate à instauraçăo, legalizaçâo e naturalizaçăo social da barbárie. Isso, sobretudo, nas perspectivas de Dalcastagné (1996) e Candido $(1972 ;$ 2004). A inserçăo de narrativas que tratam deste tema no espaço simbólico de poder que é a literatura torna-se importantíssima no sentido em que săo registros da memória socio-histórica brasileira. 
Para mais, o panorama comparativo nos explicitou que as personagens, de todas as obras, entrecruzam-se numa espécie de dialética da verossimilhança com a vida de seus autores, isso no tocante às dores, aos traumas e remissōes constituídas nas narrativas. Pois, para além das personagens, os autores entre si apresentam algo em comum em suas vivências - todos, sem exceçăo, foram e ainda săo vítimas, direta ou indiretamente, da barbárie promovida pelo regime militar brasileiro.

No tocante à tortura, esta foi instituída e aplicada, pelo regime militar brasileiro, como forma de barrar o avanço dos insurgentes. Estas açôes foram referendadas pelo Estado brasileiro. Visava promover o horror e a barbárie para desconstituir nos torturados sua identidade social e sua condiçăo humana. Contudo, apesar disso os resistentes, năo sem dor, se sobrepuseram à ditadura. Ademais, nesse sentido, foi possível entrever que toda violência advinda daí ligou-se à manutenção do status quo naquele momento, com resquícios que se alongam até os dias atuais. E que por isso năo é coerente que a sociedade atual admita, como normal que açôes de representantes do Estado, agentes da segurança pública, pagos pelos contribuintes sejam mais violentas e cruéis do que a daqueles que julgamos que deveriam estar presos justamente por serem violentos. Isso, sob pena de caminharmos a passos amplos para a uma barbárie coletiva ainda maior que a ditadura.

Por fim, sustento que a arte literária atua como espaço de remissăo e acolhimento no sentido em que busca resgatar, em autores e leitores, sentimentos como a empatia, a compaixăo, o perdăo, e, ainda promove uma reconciliaçăo entre autor e seus traumas psicológicos, sequelas deixadas pelo martírio sofrido. Năo obstante, ao desvelar múltiplas experiências humanas permite-nos, ainda que em partes, compreender o medo e a coragem do outro, sentir o que o outro sente. Nesse sentido, pode desenvolver em nós possibilidades novas de (con)viver e lidar com as angústias e os traumas (individuais e coletivos) pelos quais passamos ao longo da vida. Assim, do ponto de vista de outras vivências possíveis ela (a literatura) continua tendo muito a nos ensinar sobre reconciliar-se consigo mesmo, com o outro e com a vida de cada dia.

\section{REFERÊNCIAS}

AUERBACH, Erich. Mimesis: A representaçâo da realidade na literatura ocidental. Tradução de George Bernard Sperber. Sáo Paulo: Perspectiva, 1971.

ALVES, Marcio Moreira. Tortura e Torturados. Rio de Janeiro: Idade Nova, 1996.

BETTO, Frei. Batismo de Sangue. Rio de Janeiro: Rocco, 2006.

BUTLER, Judith. Quadros de guerra: quando a vida e passível de luto. Rio de Janeiro: Civilizaçăo brasileira, 2015.

CANDIDO, Antonio. A literatura e a formaçāo do homem. Săo Paulo: Edusp, 1972. 
.O direto a literatura. In: Vários Escritos. Săo Paulo: Ouro Sobre Azul, 2004.

COMISSĀO NACIONAL DA VERDADE. Relatório - Volume I-II-III. Dezembro de 2014. Disponível em: http://www.cnv.gov.br/images/pdf/relatorio/volume_1_digital.pdf

DALCASTAGNÉ, Regina. O espaço da dor: o regime de 64 no romance brasileiro. Brasília: UNB, 1996.

. Literatura brasileira contemporânea: um território contestado. Vinhedo: Horizonte, 2012.

GINZBURG, Jaime. Crítica em tempos de violência. Săo Paulo: Edusp/Fapesp, 2012.

PAIVA, Marcelo Rubens. Ainda estou aqui. Rio de Janeiro: Objetiva, 2015.

PELLEGRINO, Hélio. Brasil: nunca mais. Săo Paulo:Vozes,1996.

PILA, Maria. Volto semana que vem. Săo Paulo: Cosac Naify, 2015.

TAPAJÓS, Renato. Em câmara lenta. Sāo Paulo: Alfa Omega, 1977.

VIN̂AR, Maren \& VIN̂AR, Marcelo. Exílio e tortura. Sáo Paulo: Escuta, 1992.

VIEIRA, Rosângela de Lima. Ecos da ditadura na sociedade brasileira (1964-2014)/ Rosângela de Lima Vieira (org.). Sâo Paulo: Cultura Acadêmica, 2014. 278 p. 